\title{
Explaining the Mizaj Identification Criteria in Diabetic Children Baesd on Persian Medicine Experts agreement; A Delphi method
}

\author{
Morteza Mojahedi ${ }^{1}$, Majid Asghari ${ }^{2}$, Abbas Ebadi $^{3}$, Reza Ilkhani ${ }^{4}$, Zahra Aghauri ${ }^{5 *}$, Ali Montazeri ${ }^{6}$ \\ 1. Traditional Medicine and History of Medical Sciences Research Center, Babol University of Medical Science, Babol, Iran \\ 2. School of Traditional Persian Medicine, Qom University of Medical Science, Qom, Iran \\ 3. Behavioral Sciences Research Center, Life Style, Baqiyatallah University of Medical Sciences, Tehran, Iran \\ 4. School of Traditional Persian Medicine, Shahid Beheshti University of Medical Sciences, Tehran, Iran \\ 5. Isfahan Endocrine and Metabolism Research Center, Isfahan University of Medical Sciences, Isfahan, Iran \\ 6. Health Metrics Research Center, Iranian Institute for Health Sciences Research, ACECR, Tehran, Iran
}

Received: 12 December 2021

Accepted for publication: 15 May 2021

[EPub a head of print-31 May 2021]

Payesh: 2021; 20 (3): 311-322

\begin{abstract}
Objective (s): In Persian Medicine (PM) diabetes mellitus is known as a dystempramental diseases (Su-e-mizaj) and is divided into two main types, hot and cold. Achieving agreed diagnostic criteria among PM experts for standardizing such criteria for identification of two types of diabetes and its management is essential. This study aimed to examine diabetes mizaj criteria via consensus of PM physicians.

Methods: This was a cross sectional survey and conducted by the Delphy method. Diabetes mizaj symptoms was collected from PM literature, and patient and PM experts interview. Sixteen PM experts were requested to evaluate quantitative and qualitative value of these symptoms during 3 rounds of Delphi.

Results: Based on the results of third round; thirst, touch condition of hand and kidney, impressibility of air and food and face puffing, were considered as major criteria and urine color and smell and face and eye color were considered as minor criteria for identification of diabetic children Mizaj or Su-e-mizaj

Conclusion: This study extracted the agreed criteria for determining the diabetic children Mizaj. These criteria, can be used to diagnose, different Su-e-mizaj of hole body and organs and so two types of diabetes (hot and cold) in diabetic children. Quantifying the intended criteria might lead to more exact diagnosis of the patients' mizaj.
\end{abstract}

Key Words: Diabetes, Ziabites, mizaj, Delphi method

\footnotetext{
${ }^{*}$ Corresponding author: Isfahan University of Medical Sciences, Isfahan, Iran

E-mail: aganouri@gmail.com
} 


\title{
تبيين معيار هاى مورد توافق متخصصان طب ايرانى، جهت تعيين مزاج كودكان ديابتى؛ به روش دلفى
}

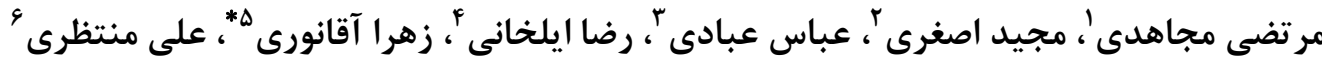

ا. مركز تحقيقات طب سنتى و تاريخ بزشكى، دانشكاه علوم بزشكى بابل، بابل، ايران

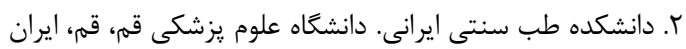

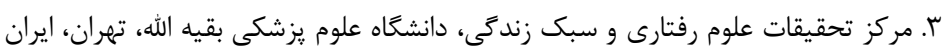

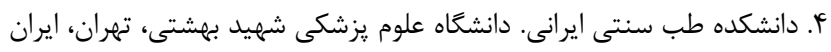

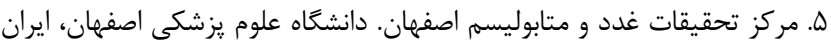

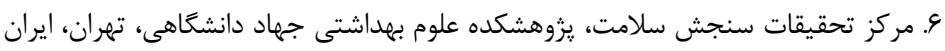

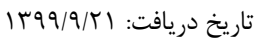

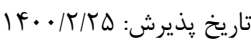

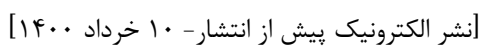

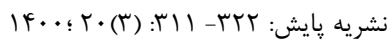

جكيده

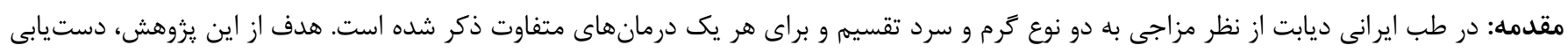

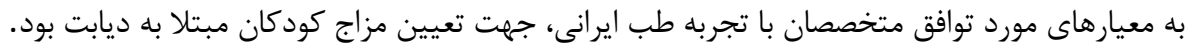

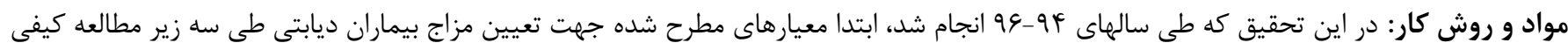

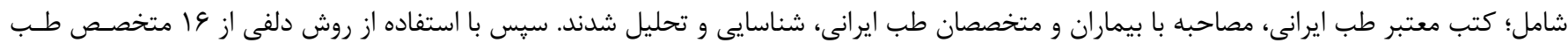

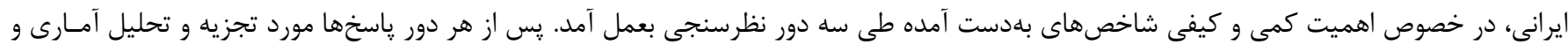

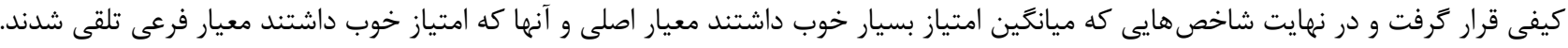

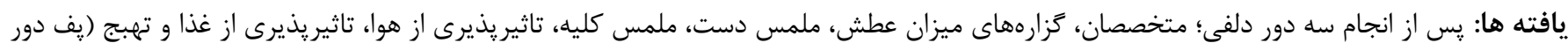

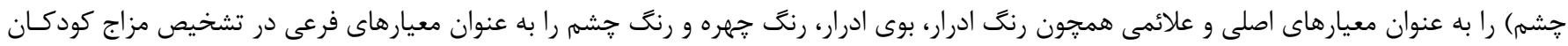
ديابتى در نظر كرفتند.

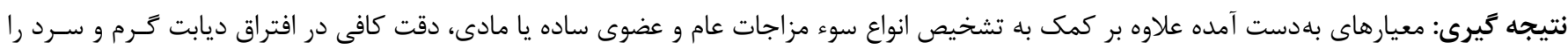

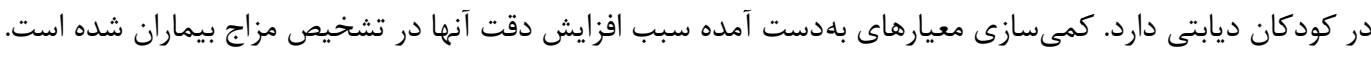




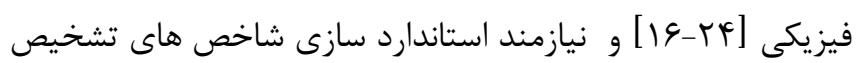

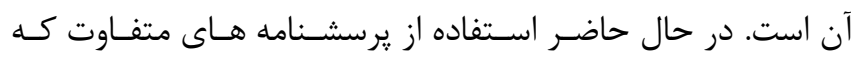

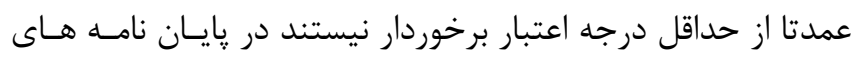

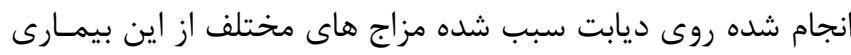

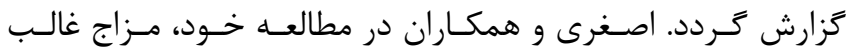

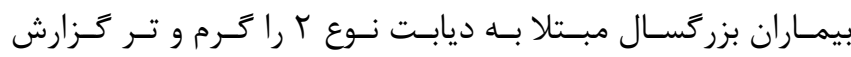

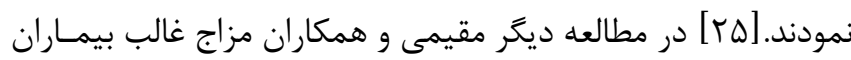

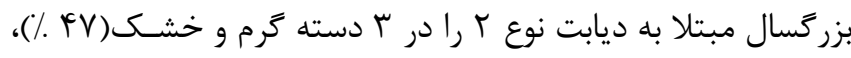

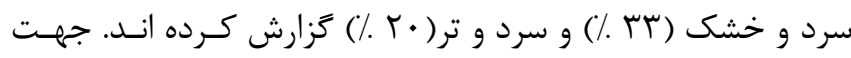

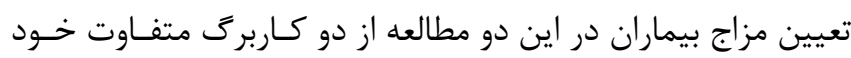

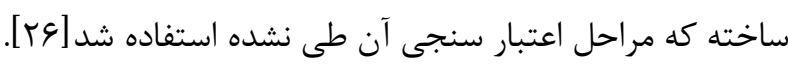

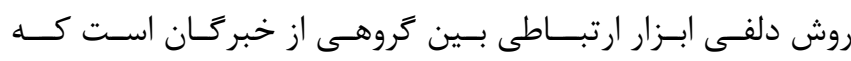

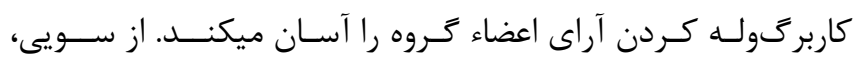

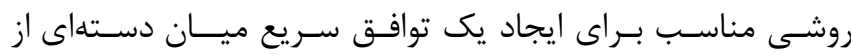

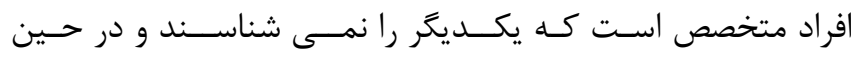

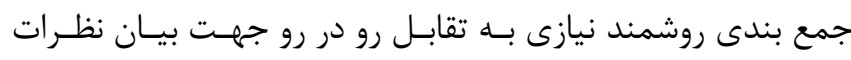

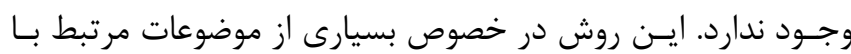

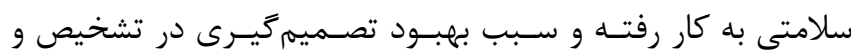

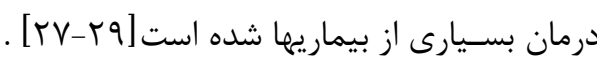

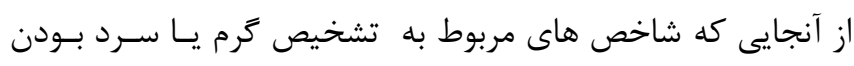

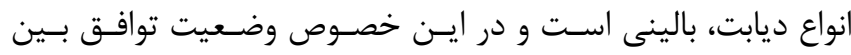

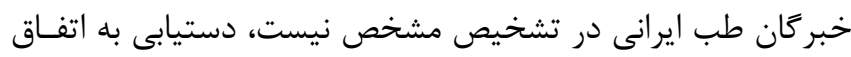

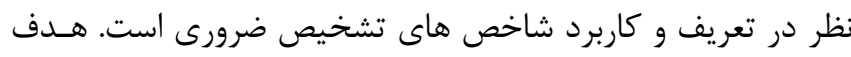
از اين يزوهش، تعيين مهمتر ين معيارهاى مـورد توافـق متخصصـان

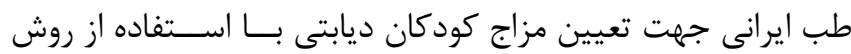

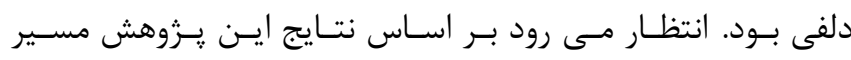

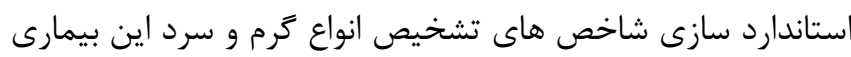
از منظر طب ايرانى جهت بررسى اثر بخشى مداخلات مد نظـر ايـن مكتب بعنوان درمان كمكى اين بيمارى، هموارتر كردد.

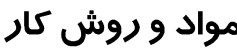

با توجه به اينكه تا كنون مطالعه اي در خصوص ماد علايم مزاجى انـواع

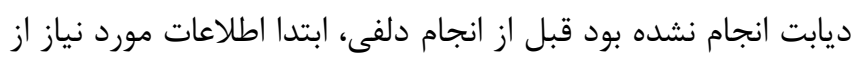
سه منبع كتب طـب ايرانى(شـامل قـانون، الحـاوى، اكسـير اعظـمه،

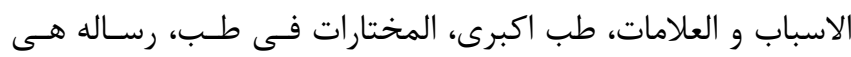

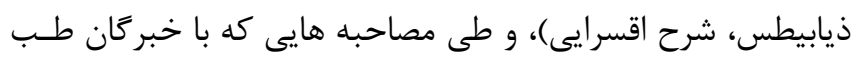

\section{مقدمه}

ديابت نوع يك، يكى ازشايع ترين بيمارى هاى مزمن دوران كودكى

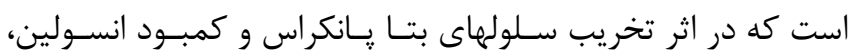

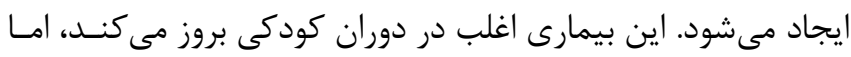

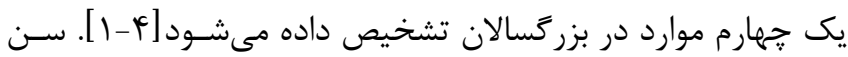

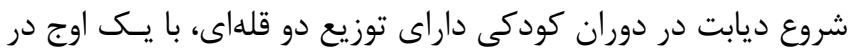

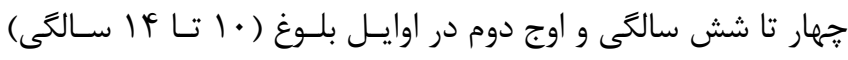

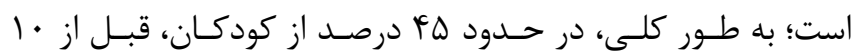

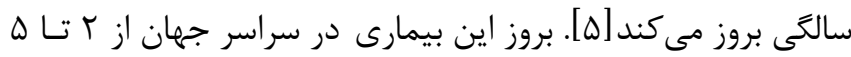

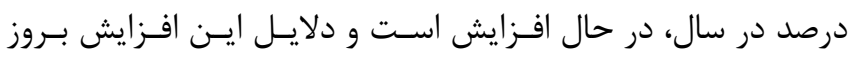

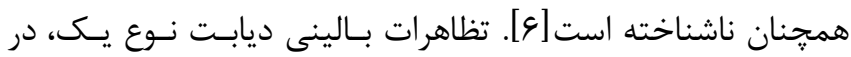
دوران كودكى مىتواند بـه صـورت شـروع علايسم كلاسـيك، شـامل

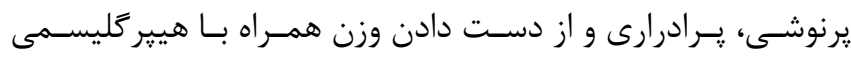

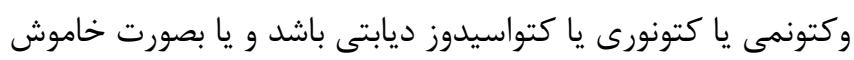

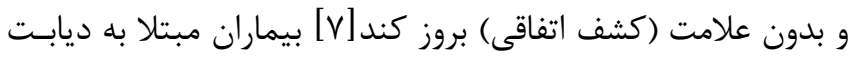

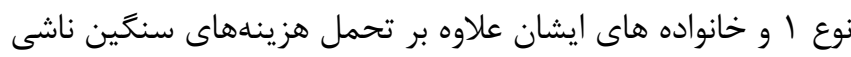

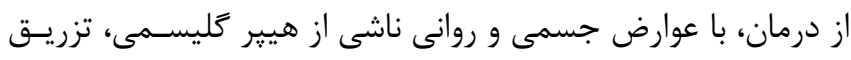

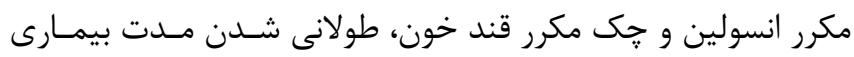

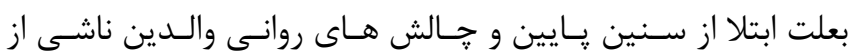

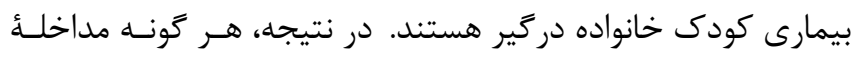

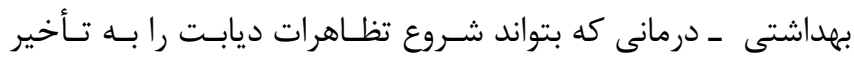

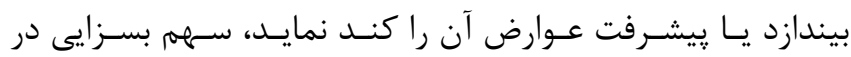

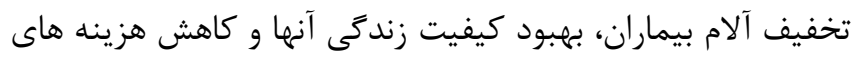

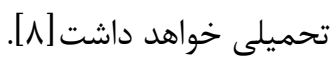

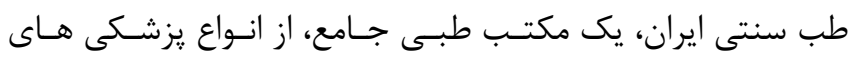

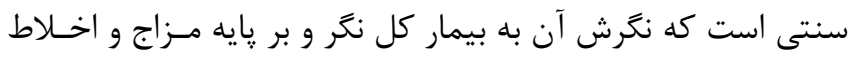

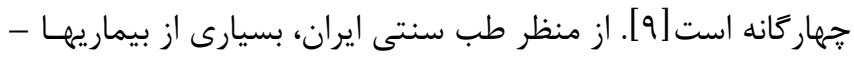

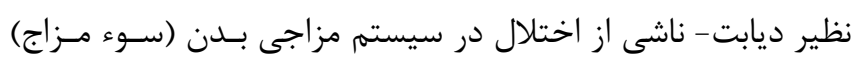

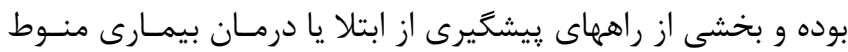

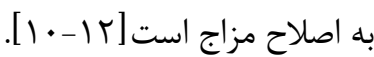

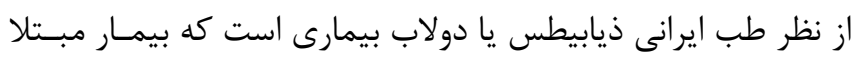
به محض نوشيدن آب، آن را از طريق ادرار دفع مى كند. همـين امـر

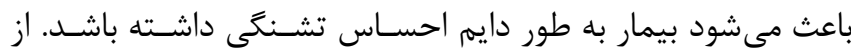

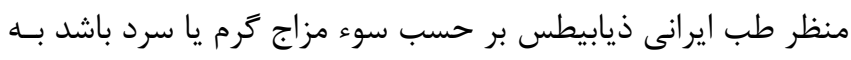

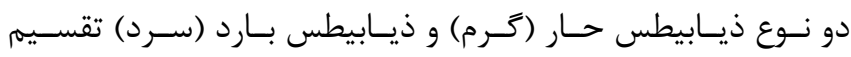

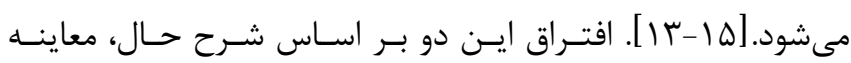


درون خوشه اى (ICC) ارزيابى شد. بـر اسـاس فاصـله اطمينـان

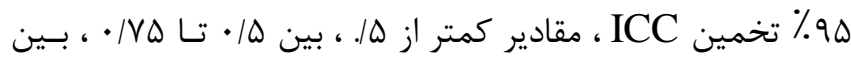

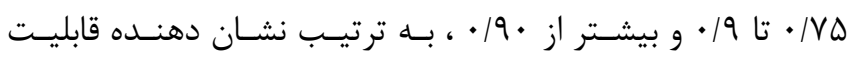

اطمينان ضعيف ، متوسط ، خوب و عالى درنظر كرفته شد. [بس].

\section{يافتهها}

نتايج مرور متون و مصاحبه ها به تفصيل در جدول شـماره آ،آمـده

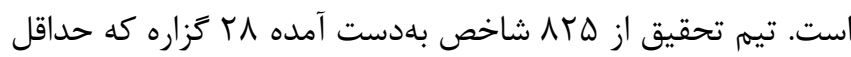

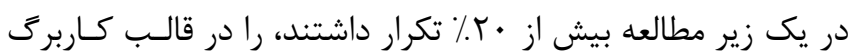

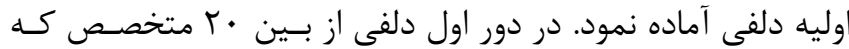

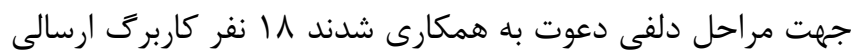

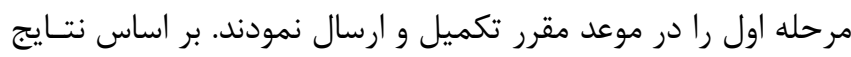
اين مرحله 19 معيار براى ذيابيطس ترم و ال 1 معيار براى ذيـابيطس سرد مورد توافق متخصصـان جهـت دور دوم دلفـى اسـتخراج شـد.

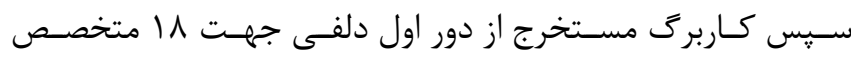

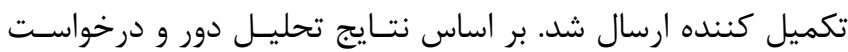
متخصصان همكار جهت سهولت در پاسخدهى، جـداول امتيـازدهى

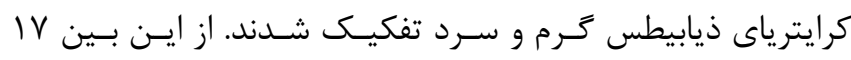
متخصص كاربرك هاى ارسـال را در موعـد مقـرر تكميـل و ارسـال نمودند. نتايج تحليل دور دوم نشان داد با ا معيـار بـراى ذيـابيطس كرم و \ معيار براى ذيابيطس سـرد مـورد توافق متخصصـان قـرار

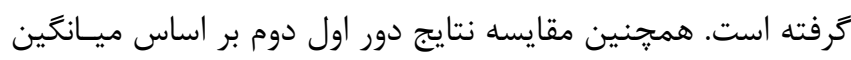

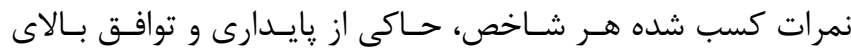

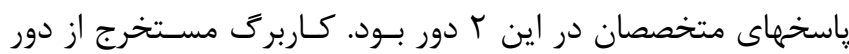

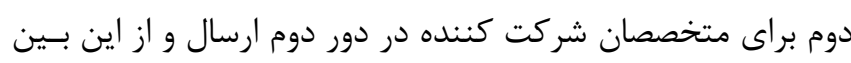

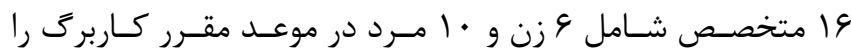
تكميل و باز ارسال نمودند. ميزان توافـق درون خوشـه اى (ICC)

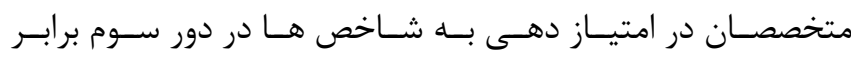
. $194 \wedge(. / \& \Delta-. / \vee q)$

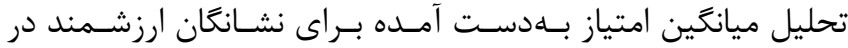

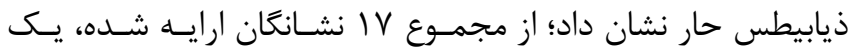

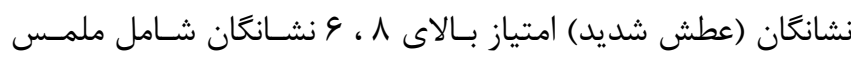

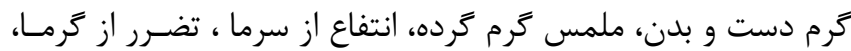

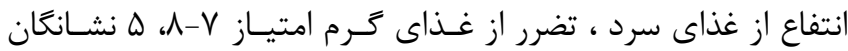

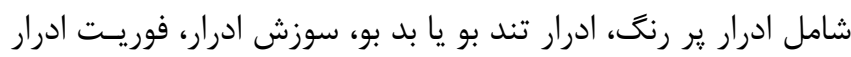

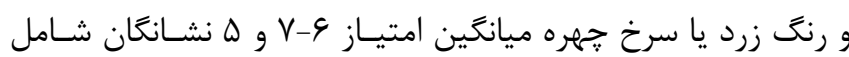
رنغ زرد يا سرخ زبان، رنغ زرد يا سرخ خشم، كاهش وزن، افزايش
ايرانى و بيماران انجام شد، در قالب سه زير مطالعه، اسـتخراج شـد.

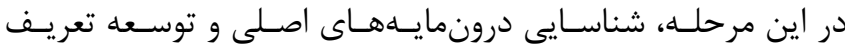

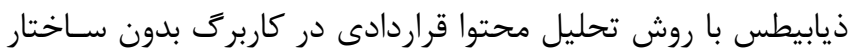

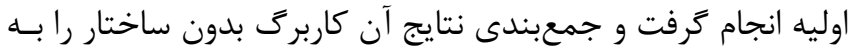
كاربركى با ساختار تبديل نمود كه اساس دور اول دلفـى رات تشـكيل مى داد. تيم تحقيق متشكل از \& متخصص طب ايرانى و Y إيدميولوزيست

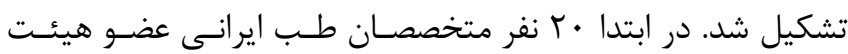

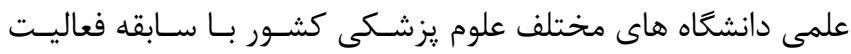
بالينى و يزوهشى در حوزه ديابت و مزاج شناسى بر اساس نظر تسيم

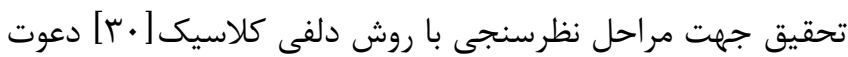

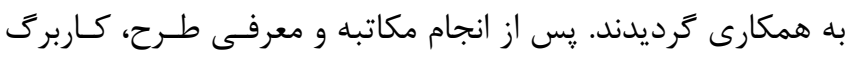

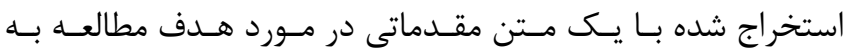
متخصصان مد نظر ارسال شد.

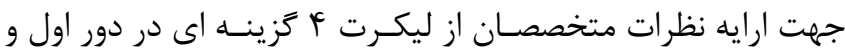

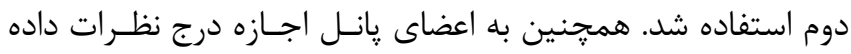

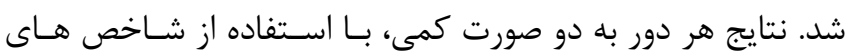

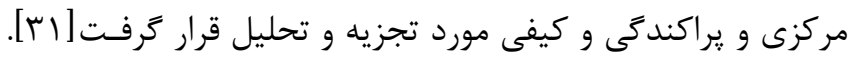

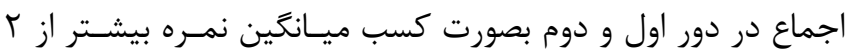

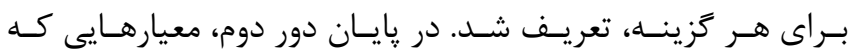

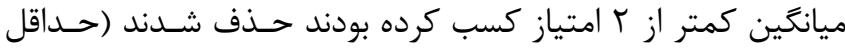

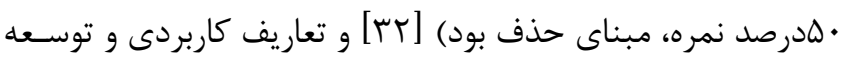
يافته هر يك از معيارهاى بركزيده با نظر تيم تحقيق تنظيم شد.

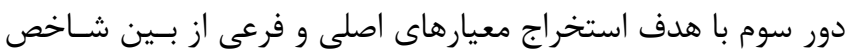

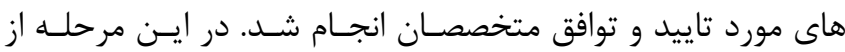

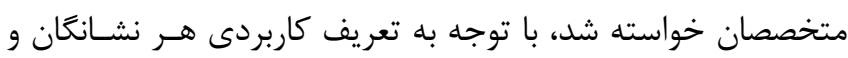

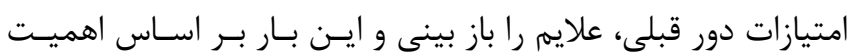

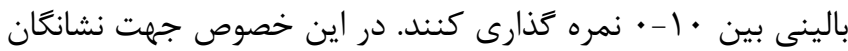

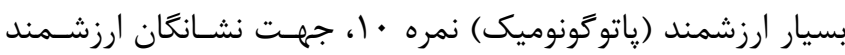

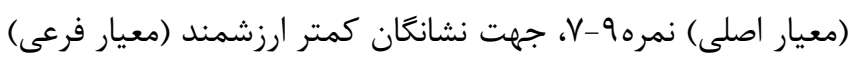

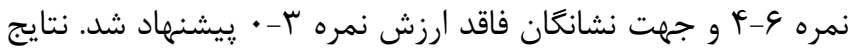

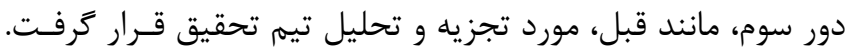

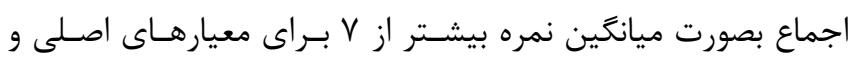

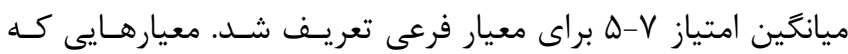

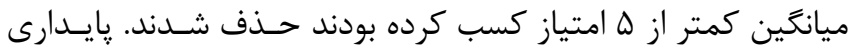

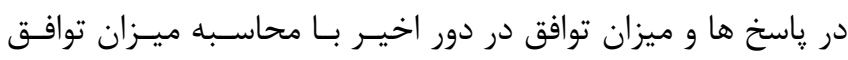


سال بيستم، شماره سوم، خرداد ـ تير .+1F

امتياز V-A، Y نشانگان شامل : ملمس سرد دست و بدن، ادرار بدون بو، عطش غير شديد و رنگ سفيد يا تيره رخسار ميانگين امتيـاز وهـ V و رنغ سفيد يا تيره زبان امتياز ه-4 كسب كرده بودند. با در نظر گرفتن نظرات متخصصان و همجنين ادغام نشانكان تضـرر و انتفاع ، تحت عنوان تاثيريذيرى از هوا و غذا، نهايتا ه نشانكان كـهـ

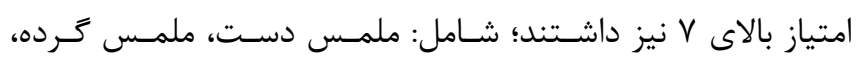

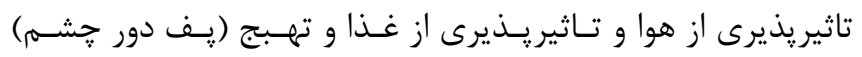

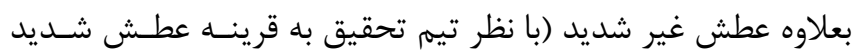

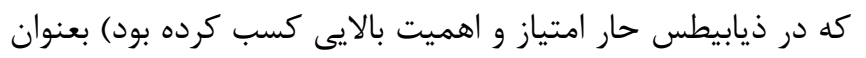

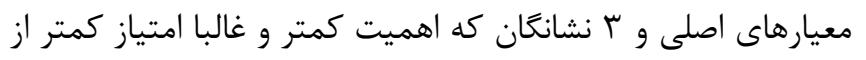

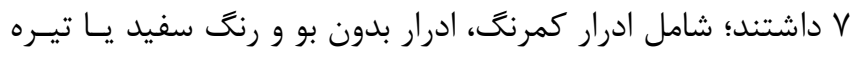

جهره بعنوان معيارهاى فرعى انتخاب شدند. رنى زبان حذف شد.

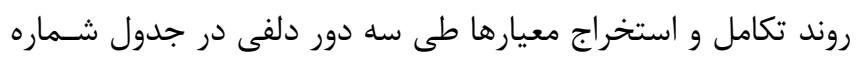

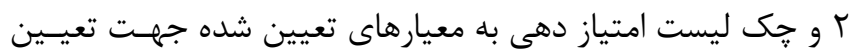
مزاج كودكان ديابتى در ييوست شماره ا آمده است.
اشتها و شب ادرارى شديد امتيـاز ه-9 كسـب كـرده بودنـد. هـيـج

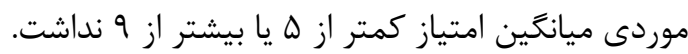
با در نظر كرفتن نظرات متخصصان و همجنين ادغام نشانغان تضرر

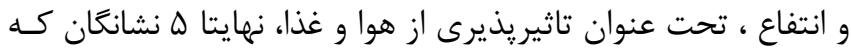

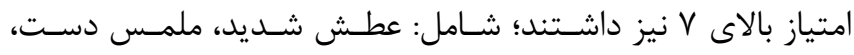

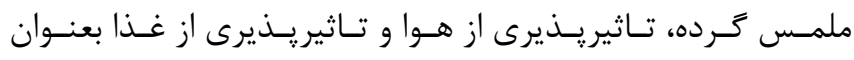
معيارهاى اصلى و ه نشانكان كه امتيـاز كمتــر از V داشـتند؛ شـامل

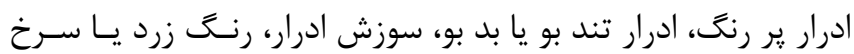

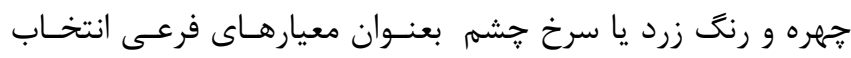

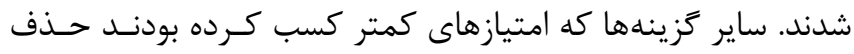
شدند. تحليل ميانگين امتياز بهدست آمده براى هر شاخص (امتيـاز

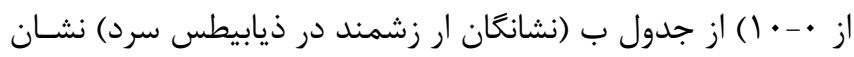

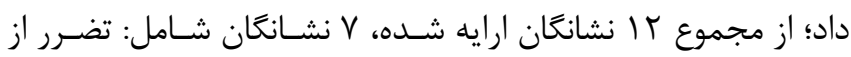

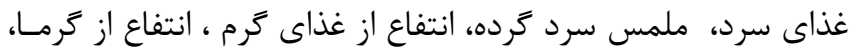

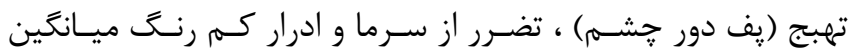

\begin{tabular}{|c|c|c|c|c|c|c|c|c|}
\hline \multicolumn{2}{|c|}{ سوءمزاجات عام در مصاحبه اساتيد } & \multicolumn{5}{|c|}{ ساتيد و در متون طب سنتى } & \multirow{3}{*}{ ذيابيطس } & \multirow[t]{3}{*}{ 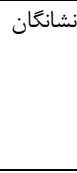 } \\
\hline & & در مصاحبه اساتيد & & در كتب & & در كتب & & \\
\hline 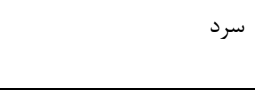 & كرم & صَرَم/ دم/ سرد/ بلغم & سرد. بلغم & 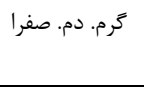 & سرد & كرم & & \\
\hline 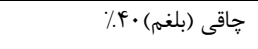 & \multirow{2}{*}{ لاغرى (صفرا) • | } & & & & 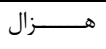 & 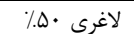 & 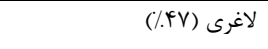 & \multirow[t]{7}{*}{ خشكى } \\
\hline لاغرى (سودا) • • & & & & & $\%$ & & & \\
\hline ريزش آب دهان (بلغم) •^^/، & خشكى مخاطات (دم) •r\% & & & & & 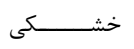 & \multirow{5}{*}{ 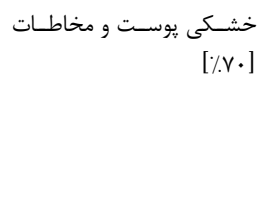 } & \\
\hline رطوبت لبها (بلغم) • 1\% & ترك زبان (صفرا) • 1٪ & & & & & عــــــــارض & & \\
\hline \multirow{3}{*}{ 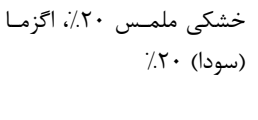 } & & & & & & نميشود •1\% & & \\
\hline & & & & & & 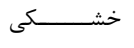 & & \\
\hline & & & & & & شديد • 11\% & & \\
\hline
\end{tabular}

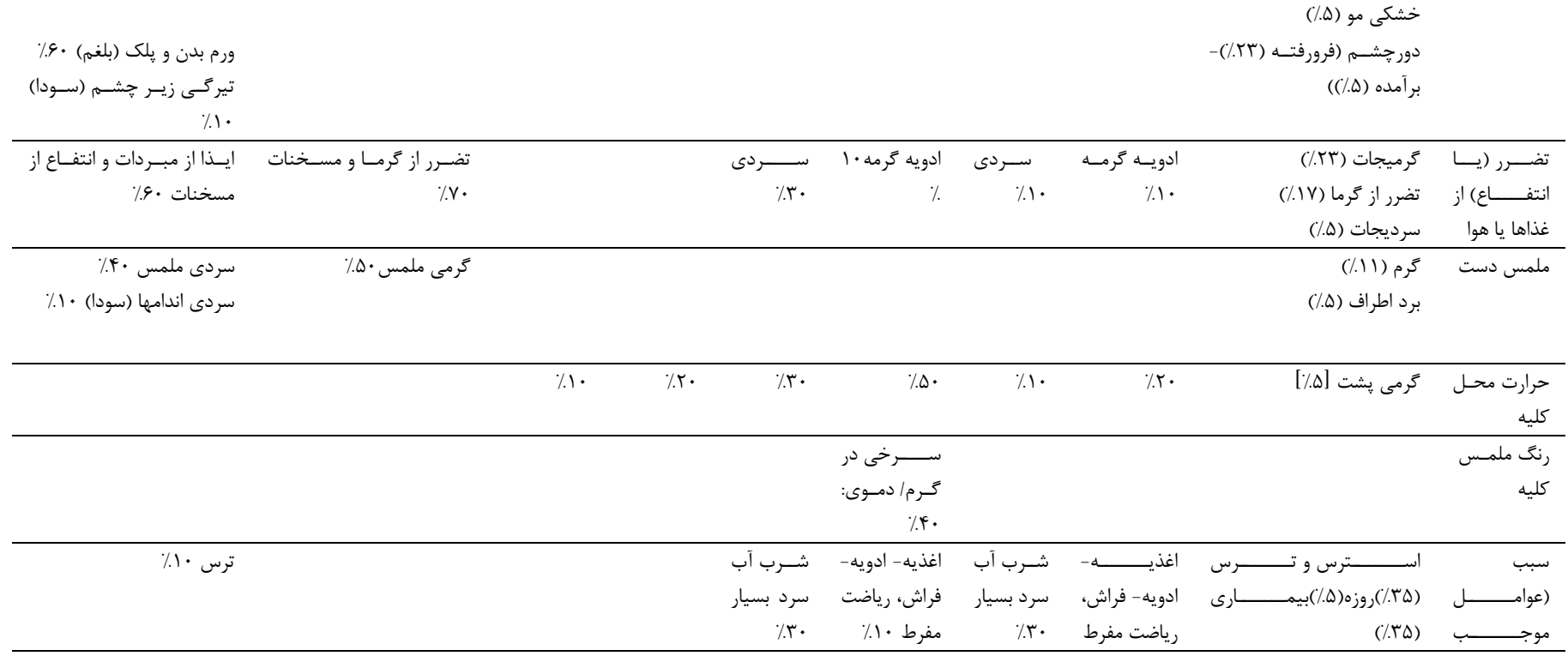


سال بيستم، شماره سوم، خرداد ـ تير If.

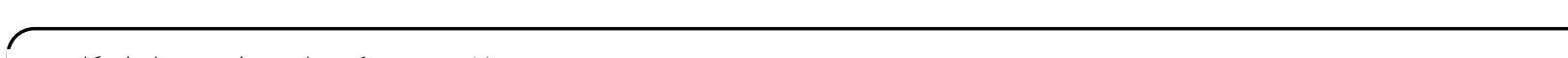

نشريه يزوهشكده علوم بهداشتى جهاددانشكاهى

\begin{tabular}{|c|c|c|c|c|c|c|c|c|c|}
\hline & & & & & & & $\%$ & & تشــــيد يـــا \\
\hline \multirow{16}{*}{ سفيدى ادرار (بلغم) • 1\% } & & & & & & & & 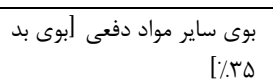 & علايم ادرارى \\
\hline & & بيرنــــــــ & زرد (كرم) & ســفيدى & ســـرخى يــــ & ســــــفيد & بيرنگ •V٪ & رنـــ ادرار (زرد) خيلـى زرد & \\
\hline & & 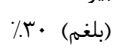 & $\%$ & $\%$ & زردى / ناريت & $\%$ & & $(/ \%)$ & \\
\hline & & تيره (سودا) & (صـــفرا) & & $\%$ & & & (مثل آب ه//) & \\
\hline & & & & & & & & & \\
\hline & & $\%$ & & & & & & 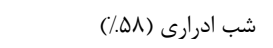 & \\
\hline & & بلغم •r٪\% & & & & $\%$ & $\%$. & يرادرارى و تواتر ادرار (MA/) & \\
\hline & & & & غلظظ بـول & & & & غلظت ادرار (11/) & \\
\hline & & & & $\%$ & & & & & \\
\hline & & & & & $\%$ & & & 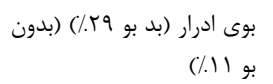 & \\
\hline & & & & & $\%$ & & $\%$ & سرعت قيام به بول [هᄉ٪] & \\
\hline & & & (َ) (َـــرم) & & $\%$. & عـــــــدم & بدون حرقـت & 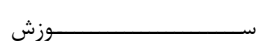 & \\
\hline & & & $\%$ & & & حرقـــت & $\%$. & ادرار (داشـت =9 ؟r/،نداشـت = & \\
\hline & & & (صفراوى) & & & $\%$ & & $\quad\left(/ .9^{9}\right.$ & \\
\hline & & & $\%$. & & & & & & \\
\hline & & & & & $\%$ & & & : جربى بالاى ادرار & \\
\hline اشتهاى كاذب (سودا) • r٪٪ & بى اشتهايى • (1/(صفرا) & & & 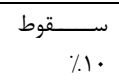 & & & & 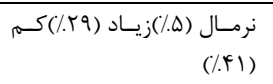 & اشتها \\
\hline سستى و كسالت(صبحكاهى) & & & & & & ضـــــف & & داشت (·lve & ضــــــــف و \\
\hline 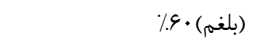 & & & & & & $\%$ & & نداشت (IVIV) & بيحالى \\
\hline سفيدى رنح رو و زبان (سرد & زردى يا سرخى رنغ جهـره & & & سفيد •٪/\% & & ســــــيد & & زرد(rه//) سفيد(ه//) & رنغ رو \\
\hline يا بلغم) •r/\% & و קشم •1\% & & & & & $\%$. & & & رنغ جشم \\
\hline \multirow{3}{*}{ 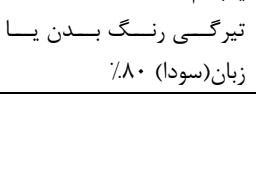 } & سرخى (دم) •V/ & & & & & & & & رنغ زبان \\
\hline & زردى •V(صفرا) & & & & & & & & \\
\hline & & & & & 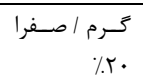 & & ن ندارد •r/ & 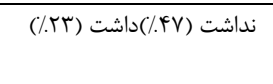 & تب \\
\hline كمى عطش ·r/ & (د) & & $\%$ & عدم/ قلـت & كثرت عطـش & تشـــنـى & شدت عطـش & آب سرد (1/.^/) & عطش \\
\hline كمى عطش (بلغم) • 1\% & • (صفرا) & & & ع. عـــــ & $\%$ & ك. & $\%$ & & \\
\hline 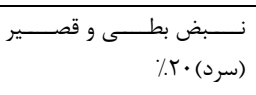 & 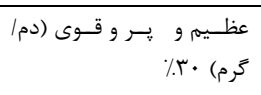 & & & & 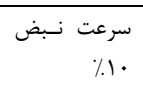 & & $\%$ & & نبض \\
\hline \multirow[t]{2}{*}{ 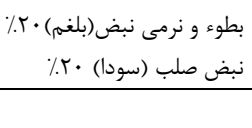 } & سرعت و تواتر (صفرا) •·r٪ & & & & & & & & \\
\hline & & & & بلغهم •r/\% & دم • ב & & & & ثقل كرده \\
\hline كندى افعال •9/: & 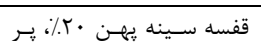 & & & ديخـر آثار & سـاير علايـهم & عـدم آثـار & & & ساير \\
\hline 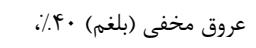 & حــرف • باء، افعـال سـريع & & & بلغم •.r/\% & دم •r/ & حسرارت & & & \\
\hline زيــادى فكــــــــــــواس و وس & •r//، عصبانيت • •r/: & & & انحنــــاى & سـاير علايسم & $\%$ & & & \\
\hline 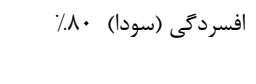 & 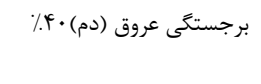 & & & 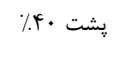 & صفرا •rr| & انشت • إى & & & \\
\hline \multirow{7}{*}{ 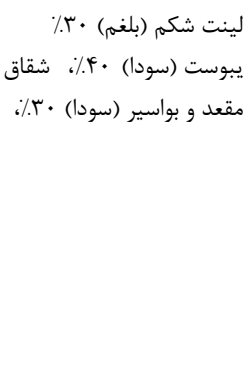 } & يبوست(صفرا) • 1\% & & & & & & & يبوست (q ז//) & \\
\hline & & & & & & & & & \\
\hline & احساس ثقل و كسالت (بويثز & & & & 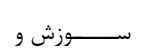 & & & وجع [11\%] & \\
\hline & 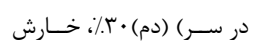 & & & & خلــــــــش در & & & & \\
\hline & محل حجامت (دم) •rّ/: & & & & صفرا •1\% & & & & \\
\hline & سوزن سوزن شـدن انـدامها & & & & & & & & \\
\hline & 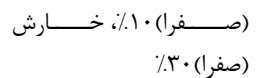 & & & & & & & & \\
\hline
\end{tabular}


سال بيستم، شماره سوم، خرداد ـ تير .+1F

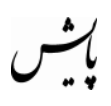

زهرا آقانورى و همكاران

تعيين معيارهاى مورد توافق ...

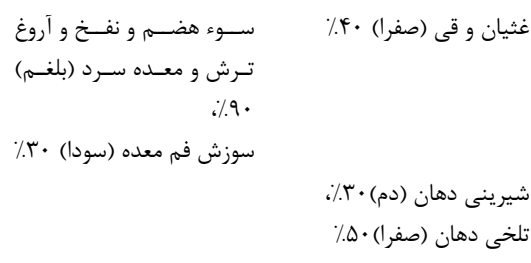

(بلغم) \%

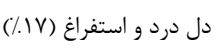

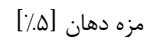

نزله

تارى ديد(ه./) ترن

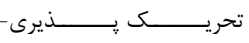

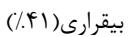

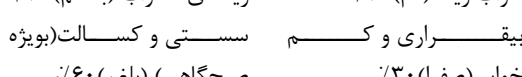

خوابى(صفرا) •r/\%

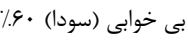

جدول rاز: روند تكامل استخراج معيارها طى سه دور مطالعه دلفى

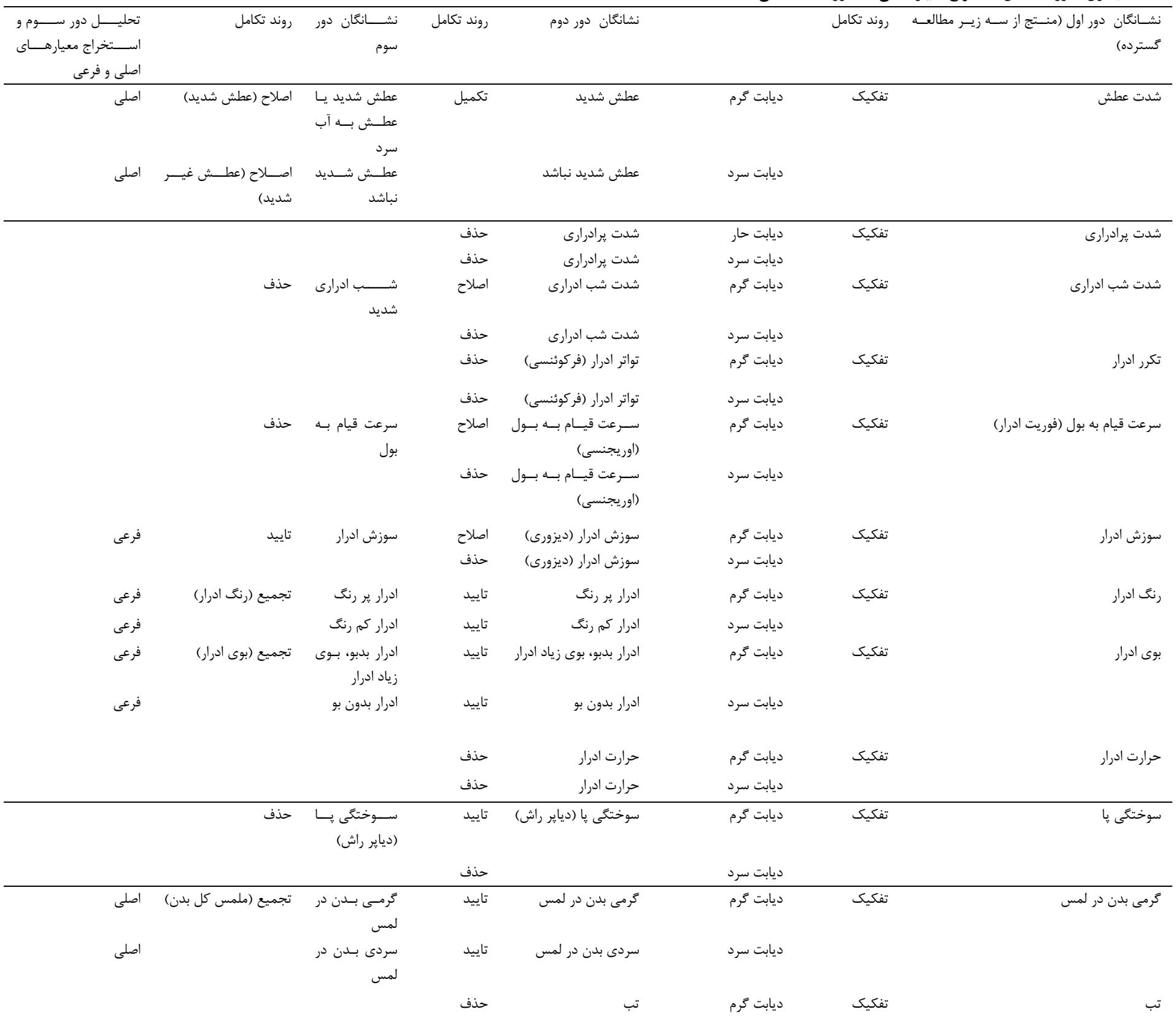


سال بيستم، شماره سوم، خرداد ـ تير If.

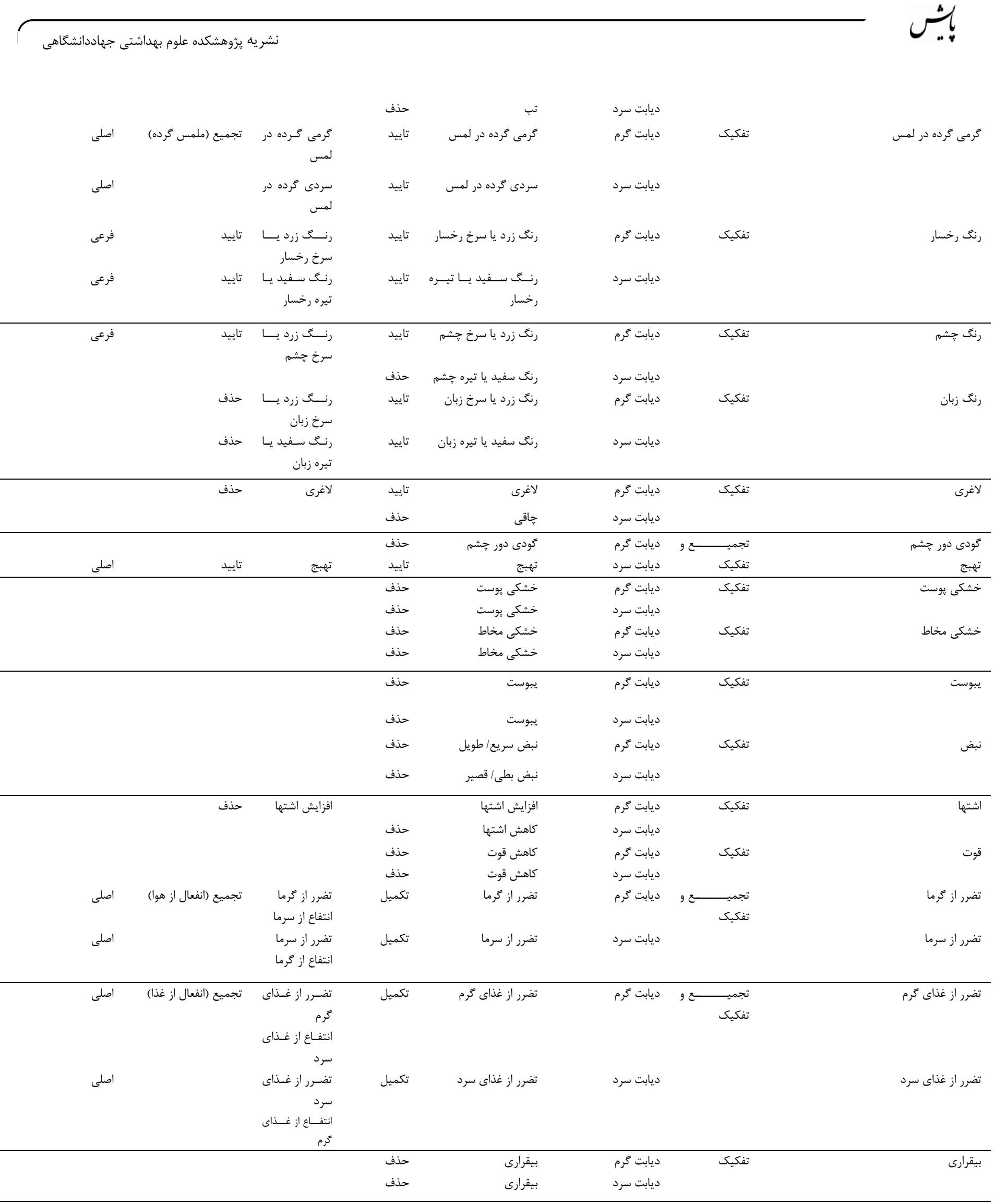


در بيماران مورد تاكيد بوده اما در متون، ذيل علايسم سـوء مزاجـات

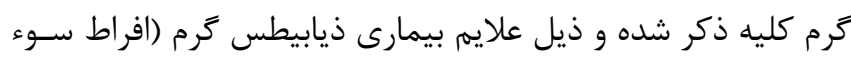

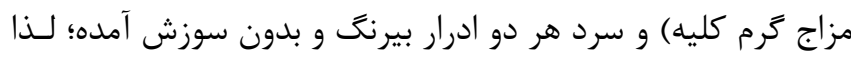

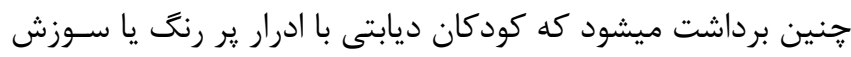

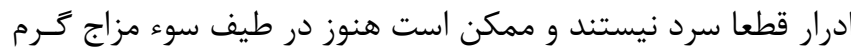

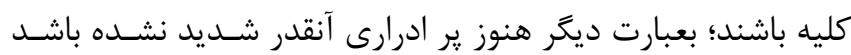

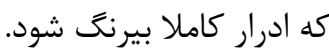
تحليل داده هاى زير مطالعه دوم (مصاحبه هاى اسـاتيد) نشـان داد: در خصوص معيارهاى تعيسين مـزاج ديابـت و عضـو كليسه بـويزهن در

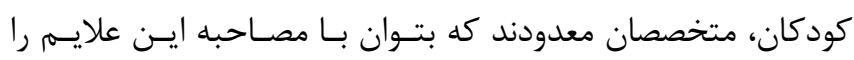
استخراج كرد و نتايج اين مصاحبه ها بيشتر در علايم مزاج بيمـاران كمك كننده است؛ درحاليكه اين موارد مبتلا به كودكان مطالعه مـا

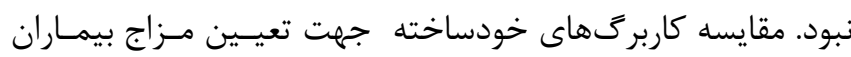

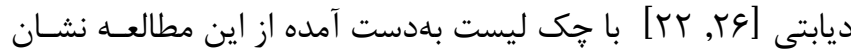

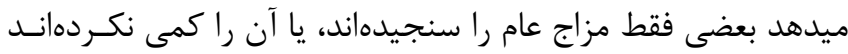

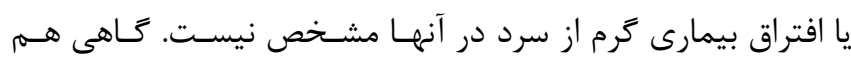
آنقدر طولانى شده كه براى كار در كلينيك مناسب نيست. بر اساس اين يافته، اساتيد در دورها دلفى معيارهـاى تعيسين مـزاج

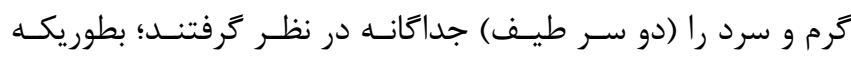
تاكيد بر شيوع بيشتر علايم كرمسى در بيمـاران، ايشـان را از علايسم ديابت سرد كه نادرتر است غافل نكند.

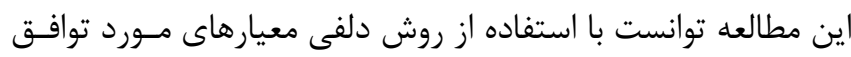

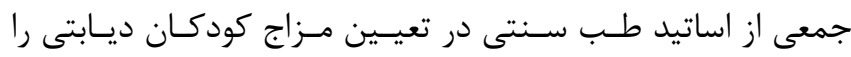
استخراج كند. روش كار در اين مطالعه سبب شد نشـانكان ابتـدايى دريى

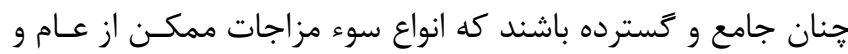
عضوى يا ساده و مادى را در بر كيرد و نهايتـا معيارهـايى اسـتخراج شد كه با اجماع اساتيد طب سنتى دقت كافى در افتراق ديابت كرم

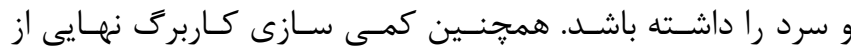

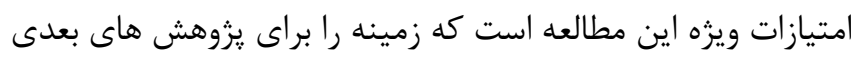

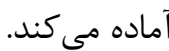
بيشنهاد ميشـود يزوهشى جهت ارزيابى و اعتبارسـنجى معيارهـاى

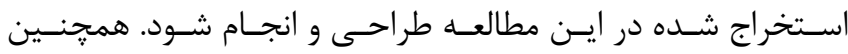

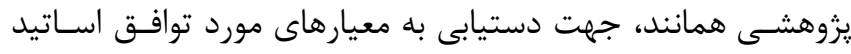
طب سنتى در ساير در مورد ساير انواع ديابت، انجام شود و با تعيين

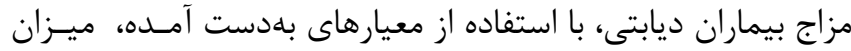
شيوع ذيابيطس گرم و سرد در ايران بررسى شود.

\section{بحث و نتيجه گيرى}

اين مطالعه براى اولين بار در طول تاريخ يزشكى، توانست در ابتدا با

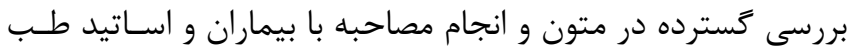

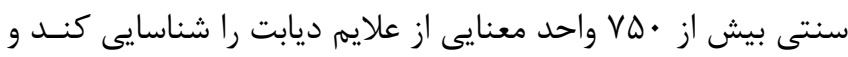

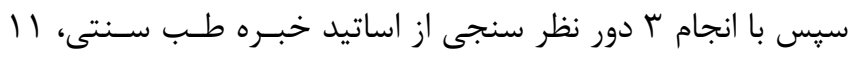

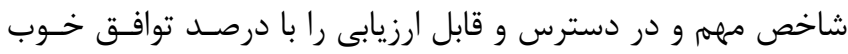

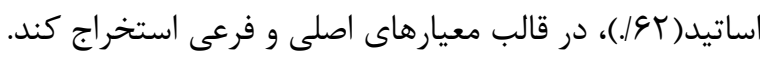
محدوديت هاى اين مطالعه شامل كمى تعداد كودكان تازه مبتلا بـهـ

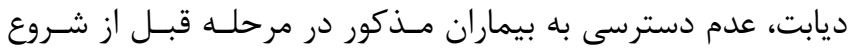

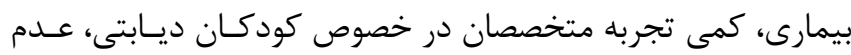

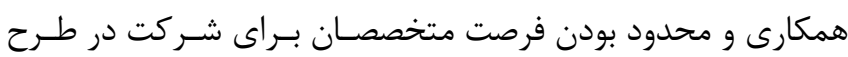

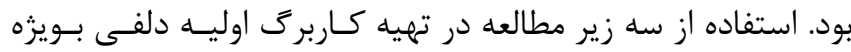
مصاحبه با بيماران سبب شد ضعف و كم تجربكى اساتيد در بيماران

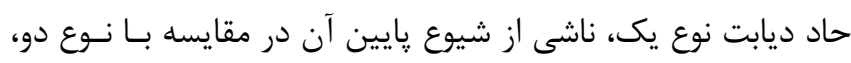

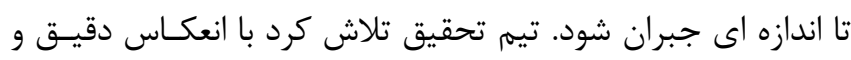

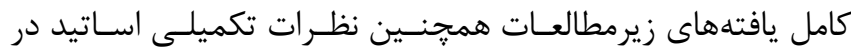

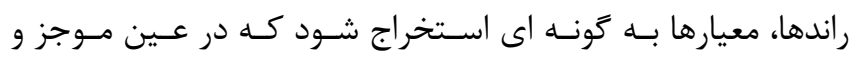

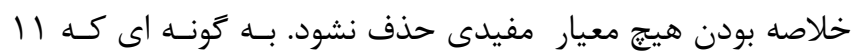

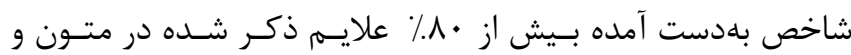

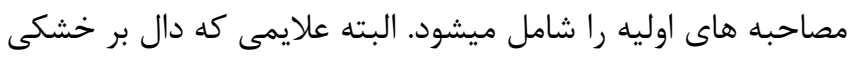

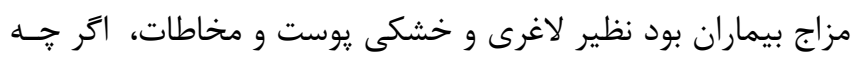

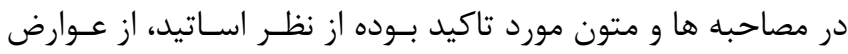

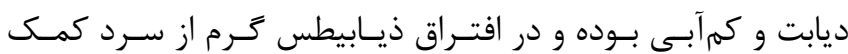

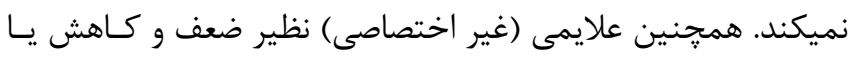

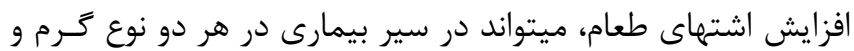
سرد ذيابيطس ديده شود. لذا از ليست معيارها خارج شدند.

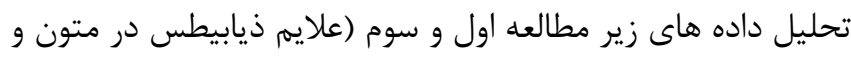

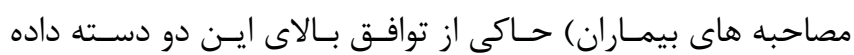
است. شاخص هايى كه در متون مورد تاكيد قرار كرفته در مصـاحبه ها هم بيشتر تكرار شده است. حتى در خصوص علايم مزاج عام كـهـ

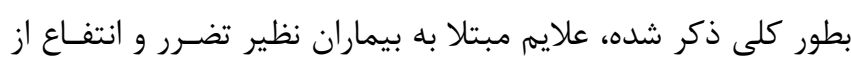

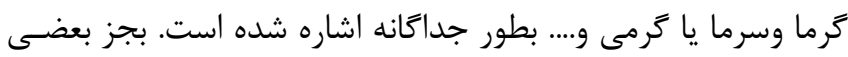
علايم نظير احساس حرارت در مجراى بول هنكام ادرار كردن، كه ما دأ

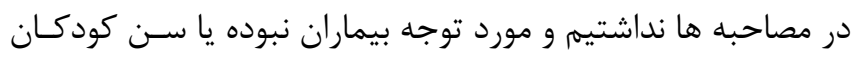
در مطالعه ما طورى نبوده كه اين احساس را بيان كنند، يا اينكه در

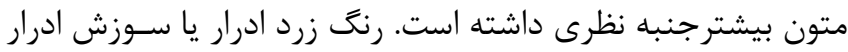




$$
\begin{aligned}
& \text { على منتظرى: طراحسى يـرَوهش، تحليـل امارى دادههــا } \\
& \text { تشكر و قدردانى } \\
& \text { اين مقاله نتيجه پايان نامه مقطع PhD بوده و بــا حمايـت دانشـعاه } \\
& \text { علوم يزشكى شهيد بهشتى انجام شده است. به ايـن وســيله مراتـب }
\end{aligned}
$$

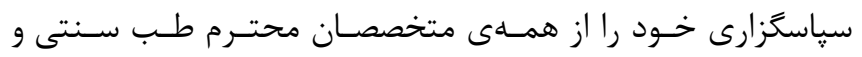

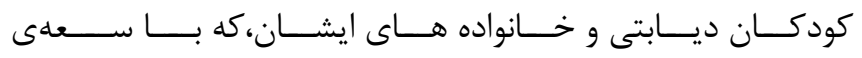

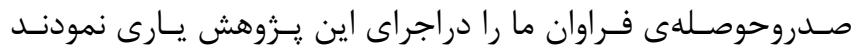

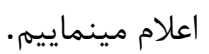

\section{منابع}

1. Group SfDiYS. The burden of diabetes mellitus among US youth: prevalence estimates from the SEARCH for Diabetes in Youth Study. Pediatrics 2006;118:1510-8

2. Fagot-Campagna A, Pettitt DJ, Engelgau MM, Burrows NR, Geiss LS, Valdez R, et al. Type 2 diabetes among North adolescents: An epidemiologic health perspective. The Journal of pediatrics 2000;136:664-72

3. Lipton RB, Drum M, Burnet D, Rich B, Cooper A, Baumann E, et al. Obesity at the onset of diabetes in an ethnically diverse population of children: what does it mean for epidemiologists and clinicians? Pediatrics 2005;115: 553-60

4. Duncan GE. Prevalence of diabetes and impaired fasting glucose levels among US adolescents: National Health and Nutrition Examination Survey, 1999-2002 . Archives of Pediatrics \& Adolescent Medicine 2006;160:523-8

5. Kappy MS, Geffner ME. Principles and practice of pediatric endocrinology. $1^{\text {st }}$ Edition, eBook Charles $\mathrm{C}$ Thomas Publicaltion Ltd: Uk, 2005

6. Legault L, Polychronakos C. Annual incidence of type 1 diabetes in Quebec between 1989-2000 in children. Clinical and Investigative Medicine 2006;29:10

7. Quinn M, Fleischman A, Rosner B, Nigrin DJ, Wolfsdorf JI. Characteristics at diagnosis of type 1 diabetes in children younger than 6 years. The Journal of Pediatrics 2006;148:366-371

8. Asghari M, Sabet Z, Davati A, Kamalinejad M, Soltaninejad $\mathrm{H}$, Naseri $\mathrm{M}$. Investigation and comparison of Ziabites disease, in Iranian traditional medicine and Diabetes disease, in classical medicine. Medical History Journal 2012; 3: 11-37

$$
\begin{aligned}
& \text { سهم نويسند }
\end{aligned}
$$

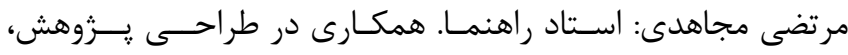

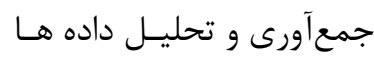

$$
\begin{aligned}
& \text { مجيد اصغرى: همكارى در جمـعآورى دادههــا و تحليــل محتـواى } \\
& \text { دادهـ } \\
& \text { زهرا آقانورى: جمعآورى دادهها و نَـارش مقاله }
\end{aligned}
$$

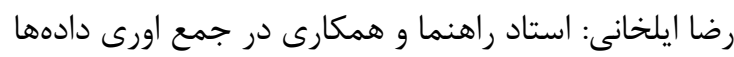

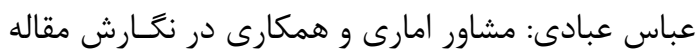

9. Zeinalian M, Eshaghi M, Naji H, Marandi SM, Sharbafchi MR, Asgary S. Iranian-Islamic traditional medicine: An ancient comprehensive personalized medicine. Advanced Biomedical Research 2015;4:191 10. Mojahedi M, Naseri M, Majdzadeh R, Keshavarz M, Ebadini M, Nazem E, et al. Reliability and validity assessment of Mizaj questionnaire: a novel self-report scale in Iranian traditional medicine. Iranian Red Crescent Medical Journal 2014; 16: 15924

11. Mojahedi M MS, Isfahani MM, Naseri M, Kamalinejad M,Khodadoust $M$, et al. . Research Priorities in Traditional Persian Medicine. Journal of Research on History of Medicine 2016;5:3

12. Naseri M, Rezaeiazdeh $H$, Taheripanah $T$, Naseri $\mathrm{V}$. Temperament theory in the iranian traditional medicine and variation in therapeutic responsiveness, based on pharmacogenetics. Journal of Islamic and Iranian Traditional Medicine 2010;1:237-42

13. Nazamuddin M, Wadud A, Ansari AH, Alam T, Perveen A, Iqbal N. Concept of Diabetes in Unani System of Medicine: An Overview .Medical Journal of Islamic World Academy of Sciences 2014;22:11722

14. Shojaii A, Dabaghian FH, Goushegir A, Fard MA. Antidiabetic plants of Iran. Acta Medica Iranica 2011;49:637-42

15. Zarshenas MM, Khademian S, Moein M. Diabetes and related remedies in medieval Persian medicine. Indian Journal of Endocrinology and Metabolism 2014;18:142-9

16. Ismail Jorjani. Al Aghraz Al Tibb Va Al Mabahes Al Alaieah [ Goals of medicin valuable disscausions]. Tehran University: Tehran, 2006: 746-8. [In Persian] 17. Arzani A. Teb-e-Akbari. Jalal al Din: Qom, 1999:826-840 [In Persian] 
18.Akhaveyni A. Hediyatol-motoallemin fi Alteb[(The Principal's of Traditional Iranian Medicine)]. Mashhad University: Mashhad, 1992 [In Persian]

19. Aghili Khorasani shirazi MH. Kholassat AlHekmah [(The Principal's of Traditional Iranian Medicine)]. In: Nazem E, editor. Esmaeilian: Qom, 2006:53 [In Persian]

20. Ibn Sina(Avicenna) H. Al-qanun Fi'l-Tibb [Contains of medicine], Dar al Kotob al Elmiyah: Lebanon, 1999: 397-9 [in Arabic]

21. Najiboddin Ali Samarghandi NA. Sharhe Asbaab o Alaamaat of Samarghandi [Explanation of medical signs by Samarghandi]. Jalal al Din: Qom, 2008: 1424 [in Arabic]

22. Azamkhan M. Exir Azam. Institue of Medical History and complementrry medcine of Iran university of Medical sciences: Tehran, 2008: 446 [In Persian]

23. Mohammad Zakariyya Razi, Al Hawi Fi Al Tibb. [Contains of medicine].Dar al Kotob al Elmiyah: Lebanon 2000: 331-344. [in Arabic]

24. Ahwazi A. Kamel- alsenaat- altebbiah. Jalal al Din: Qom, 2008: 147 [in Arabic]

25. Majid Asghari, Zari Sabet, Ali Davati, Mohammad Kamalinejad. Diabetes explanation from the perspective of Iranian traditional medicine and evaluation the effect of Ziabites capsule consumption on blood glucose control, in patients with type 2 diabetes. (Theses) Tehran: Shahed University, Medical college; 2013 [In Persian]

26. M. M. Explanation of diabetes in Iranian Traditional Medecine and modern medecine and designing type 2 diabetes diet on basis of Iranian Traditional Medecine.(Theses) Tehran University of Medical Sciece, 2015 [In Persian]

27. Hsu C-C, Sandford BA. Delphi technique. Encyclopedia of Research Design 2010:344-7

28. De Villiers MR, De Villiers PJ, Kent AP. The Delphi Technique in Health Sciences Education Research. Medical Teacher 2005;27:639-43

29. Fink A, Kosecoff J, Chassin M, Brook RH. Consensus methods: characteristics and guidelines for use. American journal of public health 1984;74:979-83 30. Ahmadi F, Nasiriyani K, Abazari P. The Delphi technique, a tool for research. Iranian Journal of Ejoucation in Medical Sciences 1999;2: 175-185 [In Persian]

31. Powell C. The Delphi technique: myths and realities. Journal of Advanced Nursing 2003;41:376-82

32. Landeta J. Current validity of the Delphi method in social sciences. Technological Forecasting and Social Change 2006;73:467-82

33. Koo TK, Li MY. A Guideline of Selecting and Reporting Intraclass Correlation Coefficients for Reliability Research. Journal of Chiropractic Medicine 2016;15:155-63 


\section{جـ ليست تعيين مزاج كودكان ديابتى، قبل از شروع درمان با انسولين}

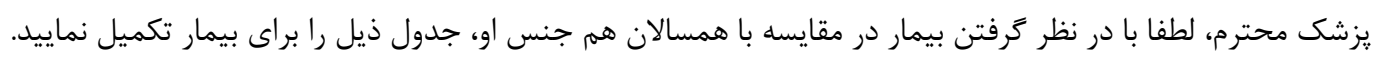
زمان شروع علائم: تاريخ تولد:... تاريخ مراجعه:...

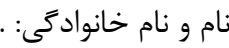

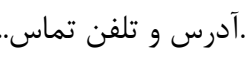

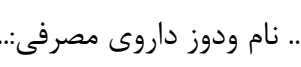

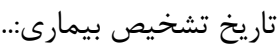

\begin{tabular}{|c|c|c|c|c|c|c|c|}
\hline امتياز & به نفــ ذيـابيطس & 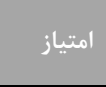 & معتدل & 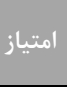 & به نفع ذيابيطس ترم & عنيار & رديف \\
\hline & سرد (Y-) & & معمولى (·) & & كرم (T) & ملمس گرده & 1 \\
\hline & سرد (ז-) & & معمولى (·) & & كرم (Y+) & ملمس كـل & r \\
\hline & 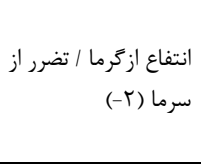 & & 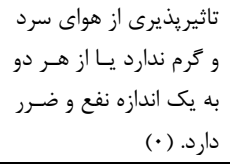 & & انتفاع از سرما/ تضرر از گرما (r+) & از هواثـــيرى & r \\
\hline & 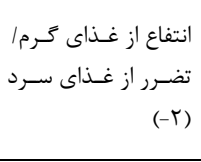 & & 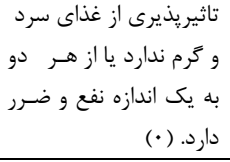 & & 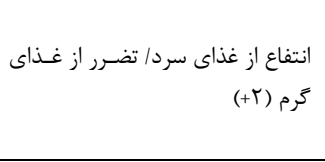 & از تاثير يـذيرى & f \\
\hline & سيرابى دارد ( - ) & \multirow{3}{*}{ غير شديد } & \multirow{3}{*}{ ندارد (•) } & & سيرابى ندارد ( (+) & \multirow{3}{*}{ شديد } & \multirow{3}{*}{$\Delta$} \\
\hline & $\begin{array}{r}\text { از شدت عطش بيقرار } \\
\text { نميشود }\end{array}$ & & & & از شدت عطش بيقرار ميشود ( (+) & & \\
\hline & ميل به آب سرد ندارد. & & & & ميل به آب سرد دارد ( (+) & & \\
\hline & دارد (ז-) & & ندارد (•) & & ندارد ( •) & تهـبـج (يـف & 4 \\
\hline & كم رنگ (1-) & & رنگ طبيعى (•) & & ير رنى (1+) & ر رنَ ادرار & $v$ \\
\hline & بدون بو (1-) & & بوى عادى (•) & & بود تند يا بد بو (1+) & بوى ادرار & $\wedge$ \\
\hline & سفيد يا تيره (1-) & & معمولى (•) & & سرخ يا زرد (1+) & رنگ رخسار & 9 \\
\hline & عدم سرخى يـا زردى & & عدم سرخى يا زردى ( •) & & سرخ يا زرد (1+) & رنَ جشم & 1. \\
\hline & ندارد (•) & & ندارد (•) & & +1 & سوزش ادرار & 11 \\
\hline & -19 & & $(\cdot)$ & & +19 & جمع & \\
\hline
\end{tabular}

توضيح جهت كاربران محترم جـ ليست:

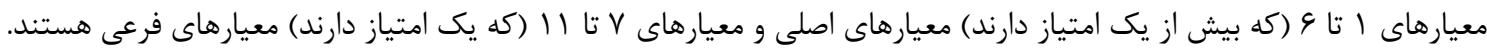

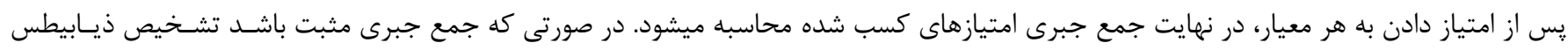

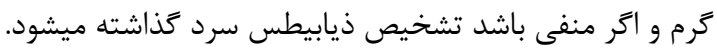

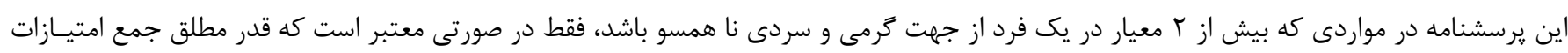
حاصله بيش از ها باشد. در موارديكه اكثر علائم بيمار، از نظر سردى و كرمى ماصى معتدل باشند با وجود حداقل ا معيار اصلى يا ؟ معيار فرعى تشخيص ذيابيطس (كرم يا سرد) كذاشته

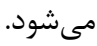
اكر كودى هيج علامتى به نفع سردى يا كرمى نداشته باشد و جمع جبرى امتيازهاى كسب شده صفر باشد، به نفع ذيابيطس سرد مىباشد. 